The University of Akron

\title{
IdeaExchange@UAkron
}

Proceedings from the Document Academy

University of Akron Press Managed

December 2018

\section{Documents and Moral Knowledge: Art in Yellowstone National Park}

Tim Gorichanaz

Drexel University, gorichanaz@drexel.edu

Please take a moment to share how this work helps you through this survey. Your feedback will be important as we plan further development of our repository.

Follow this and additional works at: https://ideaexchange.uakron.edu/docam

Part of the Applied Ethics Commons, Esthetics Commons, and the Library and Information Science Commons

\section{Recommended Citation}

Gorichanaz, Tim (2018) "Documents and Moral Knowledge: Art in Yellowstone National Park," Proceedings from the Document Academy: Vol. 5 : Iss. 2 , Article 5.

DOI: https://doi.org/10.35492/docam/5/2/5

Available at: https://ideaexchange.uakron.edu/docam/vol5/iss $2 / 5$

This Conference Proceeding is brought to you for free and open access by University of Akron Press Managed at IdeaExchange@UAkron, the institutional repository of The University of Akron in Akron, Ohio, USA. It has been accepted for inclusion in Proceedings from the Document Academy by an authorized administrator of

IdeaExchange@UAkron.For more information, please contact mjon@uakron.edu, uapress@uakron.edu. 
As the sun skids by in smallest increments across the summer sky, he draws. He begins to see how it might work, how a few black marks on a blank white field might change what's in the world.

—Richard Powers, The Overstory, 2018

As the amount of carbon dioxide in our atmosphere rises, the oceans are warming. As the earth's ice caps melt and glaciers retreat, sea levels are rising. Many of the organisms and systems that thrived at the dawn of the the Holocene are disappearing, their ecological niches now gone. As the global mean surface temperature climbs, we are experiencing unprecedented wildfires, droughts, heat waves and extreme storms. Black swans seem to be breeding and flocking. Though dramatic ebbs and flows are standard fare when it comes to the earth, experts agree that human activity has abetted these trends. If we do not change course soon, then the earth as we know it - to say nothing of humankind-has numbered days.

How to move forward? For many people, the first step is to convince climate change skeptics that there is a problem, that humans are implicated in it, and that blithe technological optimism won't solve it. To do so, they often take the tack of citing facts that they presume will be persuasive. This approach assumes that people are ideal Bayesian agents, taking due and disinterested account of each piece of evidence they encounter and adjusting the expected probabilities of various outcomes. This assumption is widespread in library and information science (Sullivan, 2018), to say nothing of other fields or the general public.

We are beginning to learn that, while this approach may work to convince some, most simply become more entrenched in their views. This is because, for us humans, many of our beliefs are simply not based on an ongoing balancing of the facts, but rather on post-hoc rationalization and cheerleading of particular views that are already held emotionally (Haidt, 2012; Schaffner \& Luks, 2018).

These days, it is common to hear that people live siloed apart in filter bubbles, that people of opposing political views read competing news sources and therefore work with different facts - that they occupy different worlds. But that picture may be too simplistic, if not outright inaccurate. For instance, while people of different political parties may seem to disagree about matters of fact, this is by and large not because they actually believe different facts. Rather, they use what on the surface appear to be factual statements to express their group membership; and if they do not know a particular fact, they will by default assume in favor of their own political party (Bullock, Gerber, Hill \& Huber, 2015). Hume's observation that reason is "slave to the passions" (Hume, 1739, p. 415) seems to be largely correct. For this reason, proposals to fight misinformation with facts (to improve fact checkers, to show people news from "across the aisle," etc.) may be largely ineffectual. 
So what can be done? In other fields, many strategies are being explored which do not assume human rationality, from subtle nudges in the built environment, to public policy, to tinkering with the algorithms that govern our digital selves. But it is not hopeless to pursue change at the individual level- to find ways to bring reason and the passions into a fruitful working relationship, to open up our selves to new ways of seeing, thinking and being. This requires an approach that is not purely epistemological, but also aesthetic and ethical. This paper is intended to inspire and guide such an approach.

\section{Documents and Moral Knowledge}

Documents have traditionally been conceptualized as material evidence - that is, as representations of reality (Buckland, 1997). But documents can also construct reality. First, given that the materials used to make a document are already part of reality, the document in itself is a material reorganization of reality, a new construction. Second, documents afford and constrain social processes, leading to new arrangements of people and technology. Third, in individuals, documents engender subjective experiences which are real in themselves and which inspire further action, thought and being.

Philosophy is traditionally divided into a number of fields, the largest of these being epistemology, ontology and ethics. The traditional conceptualization of the document is epistemological, referring to human knowing or understanding. When the material aspects of documents are considered, there is also an ontological element, referring to what exists and how it does so. But insomuch as documents play a role in constructing the future, they should be conceptualized ethically - that is, in terms of what ought to be.

In this sense, documents can be said to furnish moral knowledge, which can be defined as knowledge pertaining to how one should act in order to live best. This may be propositional in nature (taking the form of declarative sentences, e.g., knowing that something is the case), such as when you consider knowledge of why and how to invest in your retirement. But often overlooked is moral knowledge in the form of what James Young (2001) calls practical knowledge, or knowledge of how things happen or what things are like. Documents can contribute to moral knowledge in this sense in two ways. First because they directly show what things are like, which is practical knowledge in itself. That is, documents give us access to experiences relevant to moral judgment. And second, because they enhance a person's moral faculties by showing examples and allowing that person to experience things that they may also already know propositionally. This gives us practice in responding to those situations, which bears on how we act in the real world (John, 2001; Johnson, 1993; Young, 2001). As Elgin (2017) writes of art, documents exemplify particular facets of the world, flagging them up for our 
attention, thereby showing (the creator's perspective on) what people ought to value in the world and guiding action. In this paper, the objective correctness of a piece of moral knowledge is not under discussion; simply, the assertion is that art can provide a person with moral knowledge in a subjective sense, i.e., what they feel should be done.

Most of the discussions in philosophy on moral knowledge have focused on art, defined broadly to include literature and performance as well as visual art. These conversations have been productive not least because art is too often considered only as a pleasant appearance or diversion. As Wittgenstein wrote in one of his journals, "People nowadays think that scientists exist to instruct them; poets, musicians, etc. to give them pleasure. The idea that these have something to teach them - that does not occur to them" (Wittgenstein, 1980, p. 36e).

But perhaps all documents can furnish moral knowledge. Or perhaps, insomuch as a document furnishes moral knowledge, it simply is art. The thing to note is that the traditional conceptualization sees documents as providing rational demonstrations for theories, through propositional knowledge. As art, on the other hand, documents

provide insight into complex, diverse subjects where general laws are elusive or non-existent. Notably, the arts can contribute better than other forms of inquiry to the understanding of such complex phenomena as ourselves, our emotions, our relations to each other and our place in the world. (Young, 2001, p. 97)

This is the case, surely, for things that everyone would agree are art, such as Goya's The Third of May 1808 and Botticelli's The Birth of Venus. But perhaps it is also the case for any document, considered as a work of art.

\section{Art and Sustainability}

Efforts to curb climate change are often described under the rubric of sustainability. But what does that word mean? Tim Ingold (2018) contends that, for most people, sustainability is about achieving and maintaining a steady state by measuring and calculating particular phenomena in the world (numbers of species, temperature levels, etc.). But for Ingold, this is misguided. Sustainability, rather, is about carrying on-unfolding, keeping life going as a dynamic system. Ingold says that as science has committed itself to the mainstream conceptualization of sustainability, the alternative conceptualization has been taken up by art. Ingold calls for us to take art more seriously in this regard, which is deepened given the discussion of art and moral knowledge presented above.

The link between art and sustainability goes back at least to the work of John James Audubon, who, in the early nineteenth century, documented American birds through detailed illustrations. His work inspired the foundation of the 
National Audubon Society at the turn of the century. Since then, the Audubon Society has played an effectual role in bird conservation efforts (Sibley, 2013).

We can connect causal dots in this way looking backwards, but how do we do so looking forwards? For example, Audubon's spirit is carried on today in the work of artists such as Joel Santore, whose Photo Ark project seeks to document every animal species in captivity "before it's too late" through sleek, luscious photographs. Will this be an effective approach to inspire action? More generally, what makes some art effective at furnishing moral knowledge, while other art falls flat? In other words, how can we guide the creation of documents that open up new ways of seeing and acting-i.e., documents that afford moral knowledge?

To answer these questions, we need to better understand how art works when it comes to moral knowledge. To shed light on that, we can analyze two cases of artistic documentation in Yellowstone National Park.

\section{Art in Yellowstone}

Yellowstone National Park is one of our country's most treasured locales, and art figured largely in its establishment.

The American West was once terra incognita to the young nation, one which tugged at the adventurous and entrepreneurial. Westward expansion was always part of the American ethos; the frontier line had been creeping toward the Pacific since the settlers' earliest days. But that expansion was relatively slow at first, until the invention of the steam engine. As railroad lines became indispensable infrastructure in the eastern United States in the early 1800s, there was a growing incentive to employ this new technology in westward expansion. In 1853, the U.S. Congress secured funding "to ascertain the most practical and economical route for a railroad from the Mississippi River to the Pacific Ocean." With this funding, five surveys were conducted, and a tradition for large-scale surveys was established. The American conservation movement also began to unfold at this time, sparked by figures such as Henry David Thoreau, whose Walden was published in 1854, and Americans were engaged in debates over the place of the natural world in American life (Udall, 2000).

In 1871, after the transcontinental railroad had been established, geologist Ferdinand Vandeveer Hayden was one of many Americans who were enthralled by reports of the curiosities and wonders of the area called Yellowstone, in northwestern Wyoming. As a professor at the University of Pennsylvania, Hayden had been leading annual research expeditions out west, and he was determined to visit Yellowstone in that year's trip. 
Influenced by others who had traveled to Yellowstone in prior years, Hayden also became interested in the idea of championing a proposal to establish Yellowstone as the United States' first national park (on the heels of Yosemite's becoming a state park). Notably, the financiers of the Northern Pacific Railroad were also interested in this idea, as establishing a prime tourist attraction out west would bring them more profits (Nash, 1967).

In this milieu, Hayden set out on the geological survey of 1871 with a party of 32 individuals. Among them were the guest artist Thomas Moran and photographer William Henry Jackson, who were charged with visually documenting the sights. Months later, Hayden was lobbying for Congress to establish Yellowstone as a national park. He compiled a report of the expedition, which he shared with members of Congress along with Moran's watercolor sketches and woodblock prints and Jackson's black-and-white photographs. The visual materials were particularly persuasive, showing "proof that what the artist was showing really existed," in the words of Eleanor Harvey, senior curator at the Smithsonian American Art Museum (Strochlic, 2016, para. 2). Jackson claimed that it was the "wonderful coloring" of Moran's paintings that "made the convincing argument" (Wilkins, 1998, p. 6). In December, a bill was introduced in Congress, and it was signed into law on March 1, 1872, officially setting aside Yellowstone as a national park "for the benefit and enjoyment of the people."

Soon after, Moran had completed a large-scale oil painting, Grand Canyon of the Yellowstone, based on his watercolor sketches, which further galvanized the public. The painting was purchased to be placed in the U.S. Capitol, where it hung for several decades before being relocated to a conference room and later to, where it hangs today, the Smithsonian American Art Museum. The editors of The Ladies' Repository wrote, "It is the most magnificent painting we have ever beheld... It is too grand and wonderful for words to describe it, and none can ever judge of its wonders from any engraving or photograph in mere black and white" (Editorial Department, 1872, 158-159). Moran's work expressed the scale and beauty of Yellowstone, stoking Americans' interest in the natural world.

Now almost 150 years later, Yellowstone is a household name, and the American relationship to the natural world has evolved. Originally, there were no plans for conservation in the U.S. vision of the national park. There was rampant poaching and neglect. By 1901 the bison were almost extinct, and the elk were gravely threatened. In response, the National Park Service was established in 1916 to help conserve the wildlife (Quammen, 2016). Since then, conservation has been central to Yellowstone's mission-as it is the largest wild ecological zone in the continental United States - to say nothing of the other national parks. This has 
engendered a paradox: On one hand, Yellowstone is meant for human enjoyment; but on the other hand, it is meant to contribute to sustainability. "This is the paradox of Yellowstone," writes David Quammen, "and of most other national parks we have added since: wilderness contained, nature under management, wild animals obliged to abide by human rules" (Quammen, 2016, para. 6).

In 2014, photographer Michael Nichols was commissioned to expose this tension in a project documenting Yellowstone. From his previous work in Africa, Nichols learned that his photographs sparked a concern for conservation. "The only way the public will care is if we make a picture," Nichols says. "Data can't convert" (quoted in Madison, 2014, paras. 15-16). He hoped that this project would "really make people understand what they don't get now" (Madison, 2014, para. 7). In his work, Nichols always sought to document wildlife in context; in the Serengeti, for example, that involved photographing animals' social lives and their place in sweeping landscapes (Harris, 2017). But for his work on Yellowstone, this inevitably exposed the tension between humankind and wildlife.

A striking document from this project is the photograph Bison Rut, which was exhibited as part of a retrospective on Nichols in 2017 at the Philadelphia Museum of Art. Three bison dominate the foreground, hulking amidst the sagebrush, red dust stirring at their feet, legs in motion blur. They may be fighting or playing. In the background two automobiles face us. Their doors are open, and three people are standing behind the doors, cameras obscuring their faces. Perhaps they are using the doors as shields, just in case one of the beasts makes a sudden go at them. Or perhaps they are simply there as a matter of convenience, to be able to drive away more quickly as soon as they've gotten the picture.

\section{Dual Approaches to Documentation}

In his classic Wilderness and the American Mind, Roderick Nash (1967) argues that there is a dualism in the human relationship to wilderness dating back at least to the European colonization of America:

1. On one hand, we see wilderness as a store of commodities to be controlled, harnessed and profited from.

2. And on the other, we see it as a dangerous, chaotic blur that defies comprehension.

Thus Yellowstone and other national parks are at once pleasure-grounds "for the benefit and enjoyment of the people" and preserves of nature for its own sake.

We can understand the work of Moran and Nichols as responses to this dualism. They both seem to reject the first duality, the notion of controlling and profiting from wilderness, but they do so in different ways. Moran, for his part, depicts the second duality, bringing us to confront the untamed beauty of the natural world. Nichols, in contrast, depicts the first duality, as if holding up a mirror to 
society, showing us the vacuity of our actions. Quite different strategies, then, for similar ends. To be sure, these works of art are not just rhetorical; there are also elements of intrinsic motivation and skill-building in any case of art-making (Goodman, 1976). But insomuch as these works seek to influence the human relationship to nature - and both do - we can ask which approach is more effective.

\section{Art for the Future}

For art to furnish moral knowledge, which strategy is best? This is difficult to say. Of course, Moran's work facilitated the establishment of the first U.S. National Park, while whatever impact Nichols' work may have had is less easily packaged and identified, at least for now. This might lead us to think that the first strategy is more effective. But the two projects arose in quite different contexts; Moran's work easily found itself an audience with U.S. lawmakers, while Nichols' from the start was meant for the general public-but more specifically, those subscribing to National Geographic. Moreover, today's media climate is much different than that of the 1870s, given the saturation of images and the nature of internet communication. Could it be that we have become desensitized to images of sweeping beauty, seeing as they stare back at us from our desktops and calendars? Perhaps they have become inert, and being effective in the modern day calls for more irony, which Nichols' work supplies.

For now, we don't have a satisfactory answer. Still, the question should give us pause. Earth's wilderness is disappearing, if it has not already gone. Indeed, the world itself is in grave danger, as climate change unfurls. As mentioned at the beginning of this paper, in discourse around these topics we have tended to appeal to scientific documents. But if artistic documents can provision the sort of moral knowledge necessary to heal our relationship to the world, then perhaps we can also appeal to art. If that is the case, then it is worth thinking about what sort of art will serve best. 


\section{References}

Buckland, M. K. (1997). What is a "document"? Journal of the American Society for Information Science, 48(9), 804-809.

Bullock, J. G, Gerber, A. S., Hill, S. J., \& Huber, G. A. (2015). Partisan bias in factual beliefs about politics. Quarterly Journal of Political Science, 10(4), 519-578.

Editorial Department. (1872). Notes from Washington. The Ladies' Repository, 48(6), 158-159. Retrieved from https://books.google.com/books?id=Q4gUAAAAYAAJ\&pg=RA1PA158\#v=onepage \&q\&f=false

Elgin, C. Z. (2017). True enough. Cambridge, MA: MIT Press.

Goodman, N. (1976). Languages of art (2nd ed.). Indianapolis, IN: Hackett.

Haidt, J. (2012). The righteous mind: Why good people are divided by politics and religion. New York: Pantheon.

Harris, M. (2017). A wild life: A visual biography of photographer Michael Nichols. New York: Aperture.

Hume, D. (1739). A treatise of human nature. London: John Noon. Retrieved from http://davidhume.org/texts/t/full

Ingold, T. (2018, February). The sustainability of everything. Paper presented at Natures: Anthropology Colloquium Series, University of Pennsylvania, Philadelphia. Retrieved from https://www.youtube.com/watch?v=BPEAUMQ0BIM

John, E. (2001). Art and knowledge. In B. Gaut \& D. McIver Lopes (Eds.), The Routledge companion to aesthetics. London, UK: Routledge.

Johnson, M. (1993). Moral imagination: Implications of cognitive science for ethics. Chicago: University of Chicago Press.

Madison, E. (2014, October 12). National Geographic photographer documents Yellowstone. Great Falls Tribune. Retrieved from https://www.greatfallstribune.com/story/news/local/2014/10/12/nationalgeographic-photographer-documents-yellowstone/17151639/

Nash, R. F. (1967). Wilderness and the American mind. New Haven, CT: Yale University Press.

Quammen, D. (2016). Learning to let the wild be wild in Yellowstone. National Geographic. Retrieved from https://www.nationalgeographic.com/magazine/2016/05/yellowstonenational-parks-part-1/

Schaffner, B. F., \& Luks, S. (2018). Misinformation or expressive responding? What an inauguration crowd can tell us about the source of political misinformation in surveys. Public Opinion Quarterly, 82(1), 135-147. 
Sibley, D. (2013). How James Audubon captured the romance of the New World. Smithsonian Magazine.

Retrieved from https://www.smithsonianmag.com/history/how-james-audubon-capturedthe-romance-of-the-new-world-3596111/

Strochlic, N. (2016). We have a painter to thank for Yellowstone. National Geographic. Retrieved from https://www.nationalgeographic.com/magazine/2016/05/explore-thomasmoran-yellowstone-paintings/

Sullivan, M. C. (2018). Why librarians can't fight fake news. Journal of Librarianship and Information Science, OnlineFirst. doi: $10.1177 / 0961000618764258$

Udall, S. (2000). How the wilderness was won. American Heritage, 51, 98.

Wilkins, T. (with Hinkley, C. L.). (1998). Thomas Moran: Artist of the mountains (2nd ed.). Norman: University of Oklahoma Press.

Wittgenstein, L. (1980). Culture and value (P. Winch, Trans.). Chicago: University of Chicago Press.

Young, J. O. (2001). Art and knowledge. London: Routledge. 